\title{
Occupational respiratory diseases in British Columbia, Canada in 1991
}

\author{
Gustavo R Contreras, Roxanne Rousseau, Moira Chan-Yeung
}

Epidemiological surveillance programs have proved to be useful in the control and prevention of communicable disease, ${ }^{1}$ and some chronic disease such as breast and stomach cancer, ${ }^{23}$ and cardiac diseases. ${ }^{4}$ Despite their importance and the high socioeconomic impact of occupational disease, ${ }^{5}$ surveillance programs are seldom used for the control and prevention of work related diseases. ${ }^{6-8}$

Two basic approaches have been used in surveillance programs for occupational lung disease. One is based on voluntary reporting, and the other on regulation enforced reporting. Examples of voluntary reporting are the sentinel event notification system for occupational risks (SENSOR) operating in some parts of the United States since 1987, ${ }^{9}$ and the surveillance of work related and occupational respiratory diseases (SWORD) project set up in the United Kingdom in $1989 .{ }^{8}$ Examples of regulation enforced reporting are the registry for occupational diseases in Finland, ${ }^{610}$ and the mutual system for occupational accidents and diseases in Chile. ${ }^{11}$

In Canada, there is no surveillance program for occupational diseases. To evaluate the feasibility of a surveillance program for occupational lung diseases based on voluntary reporting by physicians, the Occupational and Environmental Lung Diseases Research Unit of the Department of Medicine, University of British Columbia, initiated a pilot project in 1991. This is a report of the findings during the first year.

Medicine, University of British Columbia, Vancouver, Canada G R Contreras R Rousseau M Chan-Yeung

Correspondence to: Moira Chan-Yeung, Respiratory Division, Department of Medicine, University of British Columbia, 2775 Heather Street, Vancouver, Canada

Accepted 23 May 1994

\section{Materials and methods}

REPORTING PHYSICIANS

One hundred and eighty physicians in British Columbia were invited to take part in a program of voluntary reporting of occupational lung diseases. Most were members of the British Columbia Thoracic Society. They included all respirologists and occupational

\section{Table 1 Diagnostic categories listed in the reporting card}

\begin{tabular}{|c|c|c|c|}
\hline$\stackrel{A}{C}$ & $\begin{array}{l}\text { Asthma; work related } \\
\text { Building related illnesses; } \\
\text { sick building syndrome, } \\
\text { humidifier fever }\end{array}$ & $\begin{array}{l}\text { B } \\
\text { D }\end{array}$ & $\begin{array}{l}\text { Bronchitis; work related } \\
\text { Byssinosis; cotton, flax sisal }\end{array}$ \\
\hline $\mathbf{E}$ & Inhalation accidents & $\mathbf{F}$ & Silicosis \\
\hline $\mathbf{G}$ & Asbestosis & $\mathrm{H}$ & Coalminer pneumoconiosis \\
\hline I & Hard metal pneumoconiosis & $\mathbf{J}$ & Berylliosis \\
\hline $\mathrm{K}$ & Other pneumoconiosis & L & $\begin{array}{l}\text { Hypersensitivity pneumonitis or } \\
\text { allergic alveolitis }\end{array}$ \\
\hline $\mathbf{M}$ & Metal fume fever & $\mathbf{N}$ & Lung cancer; work related \\
\hline o & Mesothelioma & $\mathbf{P}$ & $\begin{array}{l}\text { Infectious disease; ornithosis, } \\
\text { Q fever, legionellosis }\end{array}$ \\
\hline $\mathbf{Q}$ & Others; specify & & \\
\hline
\end{tabular}

medicine specialists registered with the College of Physicians and Surgeons of British Columbia, and a number of general practitioners and internists with interest in respiratory diseases located in strategic regions of British Columbia.

\section{METHODS}

The registry was started in January 1991, with methods similar to the SWORD project. $^{8}$ Physicians were asked to report, every two months, any new case of respiratory illness that they thought was attributed to exposure at work. Those who agreed to participate received a reporting card at the beginning of each reporting period. At the end of each period, they were asked to return the card and received a new one for the next period. The importance of returning the cards, even with no case report, was emphasised. Those physicians who did not return the card were contacted by letter or by telphone. The following information was required: the patient's surname and first initial, sex, age, city or town of residence, job, type of industry were he or she was working, and the suspected agent. The reporting card had a diagnostic classification of the most frequently encountered occupational lung diseases (table 1). Added comments in the card, or in the accompanying letter were also encouraged.

\section{CALCULATION OF RATES}

The labour force in British Columbia in 1991 was 1652000 workers (information from the Ministry of Finance and Corporate Relations of British Columbia). To estimate the percentage of the labour force that was covered by the participating physicians, the local health areas served by them were used. The local health areas are geographic units containing all the health resources for specific regions in the province, and are used by the British Columbia Ministry of Health to organise demographic and health information. ${ }^{12} \mathrm{By}$ assuming that all new cases of occupational lung disease were seen by a physician who worked in the corresponding local health area, we estimated the population covered by each participating physician.

\section{Results}

Of the 180 invited physicians, 69 (38\%) agreed to participate. They included 26 respirologists, eight thoracic surgeons, and 35 internal medicine or general practitioners. The participating respirologists represented 
Table 2 Comparison of cases and annual rates by diagnostic category reported to the British Columbia registry in 1991 and those reported by the SWORD project in 1989

\begin{tabular}{|c|c|c|c|c|}
\hline \multirow[b]{2}{*}{ Diagnostic Category } & \multicolumn{2}{|c|}{ British Columbia 1991} & \multicolumn{2}{|c|}{ SWORD project 1989} \\
\hline & $\begin{array}{l}\text { No } \\
\text { (\%) }\end{array}$ & $\begin{array}{l}\text { Rate } \\
\text { millions/y }\end{array}$ & $\begin{array}{l}\text { No } \\
(\%)\end{array}$ & $\begin{array}{l}\text { Rate } \\
\text { millions/y }\end{array}$ \\
\hline $\begin{array}{l}\text { Asthma } \\
\text { Pneumoconiosis: } \\
\text { Asbestosis } \\
\text { Silicosis } \\
\text { Coal miner }\end{array}$ & $\begin{array}{c}124(50 \cdot 4) \\
44(17 \cdot 8) \\
36(14 \cdot 6) \\
6(2 \cdot 4) \\
2(0 \cdot 8)\end{array}$ & $\begin{array}{r}92 \\
32 \\
27 \\
4 \\
1\end{array}$ & $\begin{array}{l}554(26 \cdot 4) \\
322(15 \cdot 3)\end{array}$ & $\begin{array}{l}22 \\
13\end{array}$ \\
\hline Mesothelioma & $30(12 \cdot 2)$ & 22 & $340(16 \cdot 2)$ & 13 \\
\hline Benign pleural disease & $13(5 \cdot 3)$ & 10 & $221(10 \cdot 5)$ & 9 \\
\hline Bronchitis or emphysema & $11(4 \cdot 5)$ & 8 & $25(1 \cdot 2)$ & 1 \\
\hline Lung cancer & $7(2 \cdot 8)$ & 5 & $63(3.0)$ & 3 \\
\hline Allergic alveolitis & $3(1 \cdot 2)$ & 2 & $133(6 \cdot 3)$ & 5 \\
\hline Inhalation accident & $3(1 \cdot 2)$ & 2 & $72(3 \cdot 4)$ & 3 \\
\hline Building related illness & $0(0)$ & 0 & $217(10 \cdot 3)$ & 9 \\
\hline Infectious disease & $0(0)$ & 0 & $100(4 \cdot 8)$ & 4 \\
\hline Others & $11(4 \cdot 5)$ & 8 & $54(2 \cdot 6)$ & 2 \\
\hline Total & $246(100 \cdot 0)$ & 181 & $2101(100 \cdot 0)$ & 84 \\
\hline
\end{tabular}

$61 \cdot 9 \%$ and thoracic surgeons $42 \cdot 1 \%$ of the total number of physicians and surgeons in that specialty registered with the College of Physicians and Surgeons of British Columbia. There were six specialists in occupational medicine in British Columbia but none of them took part. Those who did not participate indicated that they did not see patients with occupational lung diseases. Despite the low rate of participation, the population in the local health areas served by the participating physicians represented $81.5 \%$ of the total labour force of British Columbia.

During the first half of $1991,80 \%$ of the participating physicians returned the reporting cards every two months. By the end of the first year, $67 \%$ returned the reporting cards. Sixty seven percent of the participating physicians returned 5-6 cards, $14 \cdot 5 \%$ returned 3-4 cards, $17 \cdot 4 \%$ returned $1-2$ cards, and $1.4 \%$ did not return any cards.

Two hundred and forty six new cases of occupational lung diseases were reported in 1991. Table 2 shows the distribution of diseases by diagnostic category compared with the results of the SWORD project. The overall incidence of occupational lung diseases reported by physicians in British Columbia was $181 /$ million of the working population in 1991. The corresponding figure in the United Kingdom in 1989 was 84 .

The largest diagnostic group was occupational asthma for both registries. It accounted for $50 \%$ of all reported cases in British Columbia with a rate of $92 / \mathrm{million} / \mathrm{y}$; the corresponding figures in the United Kingdom were $26.4 \%$ and $22 / \mathrm{million} / \mathrm{y}$. Pneumoconiosis and malignant mesothelioma were

Table 3 Suspected agents in occupational asthma

\begin{tabular}{lc}
\hline Suspected agents & No (\%) \\
\hline Red cedar dust & $52(41 \cdot 9)$ \\
Chemicals & $24(19 \cdot 4)$ \\
Isocyanates & $20(16 \cdot 2)$ \\
Smoke inhalation & $8(6 \cdot 5)$ \\
Other wood dust & $6(4 \cdot 8)$ \\
Wheat flour & $4(3 \cdot 2)$ \\
Animal products & $4(3 \cdot 2)$ \\
Welding fumes & $4(3 \cdot 2)$ \\
Grain dust & $1(0 \cdot 8)$ \\
Others & $1(0 \cdot 8)$ \\
Total & $124(100)$ \\
\hline
\end{tabular}

the next two most common reported diseases, then benign pleural diseases in both registries. Building related illness and infectious diseases were not reported in British Columbia whereas these two diseases accounted for $10.3 \%$ and $4.8 \%$ of reported cases in the SWORD project.

Table 3 shows the suspected agents for work related asthma. The most frequently suspected agent was western red cedar. Isocyanates were in the second place.

\section{Discussion}

Although the participation rate was low in this registry, the physicians that took part served areas with $81.5 \%$ of the work force of the British Columbia. A total of 246 new cases of occupational lung disease were reported in 1991 , giving a rate of $181 / \mathrm{million} / \mathrm{y}$. This rate is higher than the $84 / \mathrm{million} / \mathrm{y}$ reported by the SWORD project in 1989 for the United Kingdom. It is unlikely that the higher rate of occupational lung diseases in British Columbia is due to duplication of reporting as we have eliminated individuals with the same name and initials.

Work related asthma was the most common occupational lung disease reported in British Columbia. The rate of work related asthma was higher than that reported in the United Kingdom in $1989^{\circ}$ and similar to the rate of 71/million reported in Finland in 1981. Thus our study confirmed that work related asthma has become the most common occupational disease in developed countries. It should be pointed out that not all cases of work related asthma in British Columbia were proved by objective tests.

It is interesting to compare the disease categories reported by the two registries even though the year of reporting was two years apart. The relative importance of pneumoconiosis, mesothelioma, and lung cancer after work related asthma in the United Kingdom and in British Columbia were similar. Infectious diseases and building related diseases were not reported at all in British Columbia. The reason for this difference is not clear. It could be due to differences in the type of occupation or that these two diseases were not recognised as occupational lung diseases by physicians in British Columbia.

Exposure to isocyanates is the most prevalent cause of work related asthma in developed countries. In British Columbia, western red cedar dust is the most common causal agent reported in work related asthma, followed by isocyanates. This is not surprising as the forest industry is the main employer in this province. The population exposed to individual agents is not available for us to calculate the rate of work related asthma in high risk industries.

This study showed some of the problems encountered by registries of diseases based on voluntary reporting. One problem is the low participation rate and the other is the difficulty of keeping up the enthusiasm after a while. The rate at which cards were returned 
declined progressively with time and towards the end of the first year, only $67 \%$ of the participating physicians returned the cards despite interim reports that were sent to them every two months, and telephone reminders when they failed to return the reporting cards. The SENSOR project in the United States also cited the low rate of physician participation as one of the most important limiting factors for the project. ${ }^{9}$

In summary, the voluntary reporting of occupational lung diseases in British Columbia was successful during the first year. The incidence of occupational lung diseases in British Columbia was $181 /$ million/y. Work related asthma was the most commonly reported occupational lung disease, accounting for $50 \%$ of all reported cases.

We express our gratitude to all physicians who took part in this registry, and to Dr JC McDonald for his advice in setting up the registry.

1 Chorba TL, Berkelman RL, Safford SK, Gibbs NP, Hull HF. Mandatory reporting of infectious diseases by clinicians. $¥ A M A$ 1989;262:3018-26.

2 Henderson C. Breast cancer. In: Wilson J, Braunwald E,
Isselbacher K, Petersdorf R, Martin J, Fauci A, et al, eds Harrison's principles of internal medicine, 12th ed. New York: McGraw- Hill, 1991:1612-21.

3 Qin DX, Wang GQ, Zuo JH, Zhang XH, Yuan FL, Li MS, et al. Screening of oesophageal and gastric cancer by occult blood bead detector. Cancer 1993;71:216-8.

4 Bierman E. Atherosclerosis and other forms of arteriosclerosis. In: Wilson J, Braunwald $\mathrm{E}$, Isselbacher $\mathrm{K}$, Petersdorf R, Martin J, Fauci A, et al, eds. Harrison's principles of intermal medicine, 12th ed. New York: principles of internal medicine,

5 Freund E, Seligman PJ, Chorba TL, Safford SK, Drachman JG, Hull HF. Mandatory reporting of occupational diseases by clinicians. $7 A M A$ 1989;262:3041-4.

6 Keskinen H. Registers for occupational diseases. BMF 1991;303:597-8.

7 Spiegel J, Yassi A. Occupational diseases surveillance in Canada: a framework for considering options and opportunities. Can Y Public Health 1991;82:294-9.

8 Meredith S, Taylor V, McDonald J. Occupational respiratory disease in the United Kingdom 1989: a report to the British Thorac Society and the Society of Occupation British Thor Society and the Society of Occupational 1991;48:292-8.

9 Levy B, Johnson A, Rest K, Wegman D, Sencer D. Evaluation of the sentinel event notification system for occupational risks (SENSOR). New York: National Institute for Occupational Safety and Health, 1992.

10 Keskinen $H$. Epidemiology of occupational lung diseases: asthma and allergic alveolitis. XI International congress of allergology and clinical immunology: proceedings of invited symposia. London: Macmillan, 1983.

11 Asociacion Chilena de Seguridad. Normas legales sobre accidentes del trabajo y enfermedades profesionales. Santiago, Chile: Imp Atelier, 1992.

12 Nicholls CL, Ho KK, Foster LT. Local health area statistical profiles for British Columbia. British Columbia, Canada: profiles for British Columbia. British Columbia, Canada:
Ministry of Health and Ministry Responsible for Seniors, 1992. 